\title{
Impact of Traffic Pollution on Historic Buildings in Lahore
}

\author{
R. K. Sherwani, Dr. Z. Shahid, and Dr. M. Asim
}

\begin{abstract}
Lahore, the historic city, the cultural capital with thousands of monument and historic buildings especially from Mughal period is affected by the urban development. Historic buildings act as a strong visual reminder of the past and serve as a vault carrying centuries old secret treasures and as relics to the civilizations that have once part of the ancient times. Not only they connect people with the heritage but also help them to decide, how they should appropriately define themselves. Unfortunately the numbers of historic buildings in Lahore are facing issues due to the negligence, new infrastructure development, environment degradation and factors as aging and natural decay. It is important that the numbers of buildings with historic importance are on the verge of destruction due to $27.1 \mathrm{Km}$ long orange line metro train project. This paper provides a view that increased traffic flow and new infrastructure development (orange line metro) impact the historic buildings and GIS technology is helpful to determine the environmental impact of different pollutant Gases due to traffic on these historic buildings in Lahore city.
\end{abstract}

Keywords - GIS, Historic buildings, Air Pollution, Traffic

\section{INTRODUCTION}

Cultural properties are important to us and are indispensable to our world; from them we get information about our past, History, Culture, traditions and social norms .This Provide basis for technological advancement in all aspects of our life. [1] Despite of conservation efforts, Government of Pakistan and department of archaeology have failed to preserve some important sites of historical importance due to the laid down new development projects.

The air pollution has become one of the major concerns in our modern societies, which affects our health, environment, materials, structures and eco-system. The evaluation of the environment and its effects calculation on preventive historic sites is a critical task these days. The invisible damage to historical site mainly depends upon two main factors (1)-Pollutant gases and (2) particulates matters. The world health organization have termed six major elements as "classic" which are extremely dangerous to health including, lead $(\mathrm{Pb})$, Total suspended particles, Ozone (O3), Carbon monoxide

Manuscript received July. 25th, 2016 . (This work was supported by School of Architecture and Planning, University of Management and Technology, Lahore, Pakistan).

R. K. Sherwani (Assistant Professor) (Corresponding Author) is with the School of Architecture and Planning, University of Management and Technology, Lahore, Pakistan.

Dr. Z. Shahid (Assistant Professor) is with the School of Architecture and Planning, University of Engineering and Technology, Lahore, Pakistan

Dr. M..Asim (Assistant Professor) is with the School of Architecture and Planning, University of Engineering and Technology, Lahore, Pakistan
(CO), Sulfur dioxide (SO2) and nitrogen dioxide (NO2) [2]. In order to better understand the knowledge of pollution effects is the ability to use satellites and Geographic Information System (GIS).[3] In order to simulate environmental pollution several mathematical models and analysis have been used but software tool with efficient spatial functionality like (GIS) provides us flexibility for creating information products. [4] A variety of Data identified by the geographical location or spatial references is managed by these computer based tool, which helps us not only in linking the data, geographical location along with the maps and drawings but also increases visibility and provide visual extent to pollutant contamination, land use and pollution monitoring locations. [5]

Geographical locations affected by different pollutants emitted by different sources are main factor of influence. Urban areas are more affected by the pollution because of the primary sources of pollutant emission like nitrogen dioxide and Sulphur dioxide. [6]

Increasing rate of energy demand, fuel substitution like high emitting coal and oil, and greater energy intensity are the basic factors contributing to air pollution all over the world. Transmission and distribution losses in power generation are also major contributor of high energy intensity especially in third world countries. The average increase in sulfur dioxide, nitrogen dioxide and particulate matter is tremendous in last twenty years in major cities of Pakistan and exceed the WHO prescribed limits. Per capita greenhouse gas emissions are far below the global average.[7] A strong impact on increased pollutant level have been seen by road side traffic congestion and meteorological factors by many studies including those of [8], [9]

$\mathrm{SO} 2$ and $\mathrm{NO} 2$ are results in formation of sulfuric acid and nitric acid simultaneously which destroy the historic fabric of the buildings in rains. [10]The areas where the weather is dry these gases become part of the smoke and dust and rest on the surface of the buildings which can cause corrosion and complex chemical reactions when they become wet. Ozone is an important component of photochemical smog and this ground level ozone is the result of reaction between burning coal, gasoline and other fuels and part of solvents like perfumes and sprays etc. [10] Atmospheric pollution penetrate into many places and has an adverse effect on historic structures and properties.[1]

The 『SO》^2 4-, NO3-, CL-,Negative ions and $\mathrm{Na}+\mathrm{Ca}+$, $\mathrm{Mg}+, \mathrm{K}+, \mathrm{NH} 4+$ Positive ions and other chemical substances present in the environment are the basic cause of deterioration in the historic structures. [1] 
The effect of air pollution [11]

The effect of air pollutant $\mathrm{CO} 2$ on marble:

$\mathrm{CaCO}_{3}+\mathrm{CO} 2+\mathrm{aq}=\mathrm{Ca}_{2}(\mathrm{HCO} 3)_{2}{ }^{2}$

The effect of air pollutant $\mathrm{SO} 42$-on marble:

$\mathrm{CaCo} 3+\mathrm{SO} 2+0.5 \mathrm{O} 2+\mathrm{aq}=\mathrm{Ca} 2 \mathrm{SO} 42$ (i:e plaster) $+\mathrm{CO} 2$

The effect of air pollutant nitrous oxide on marble

$\mathrm{CaCO} 3+2 \mathrm{No} 2+0.5 \mathrm{O} 2+\mathrm{aq}=\mathrm{Ca}_{2}(\mathrm{NO} 3)_{2}{ }^{2}+\mathrm{CO} 2$

The parameter selection for the calculations of the environmental effects are of esteem importance is of low cost, easy to handle and meeting the modern technical demands of the literary world. The instrument used to measure the environmental pollution are mentioned in the table above at various sites along the routes of the orange line metro and the results are interpreted while using GIS software Arc GIS in Arc Map. Damage to Cultural Properties made of Stone:

\begin{tabular}{|c|c|c|c|c|c|c|}
\hline $\begin{array}{l}\text { Air } \\
\text { Pollutant }\end{array}$ & $\begin{array}{l}\text { Monitorin } \\
\text { g } \\
\text { Technique }\end{array}$ & $\begin{array}{l}\text { Instru } \\
\text { ment } \\
\text { Used }\end{array}$ & $\begin{array}{l}\text { Refer } \\
\text { ence } \\
\text { Meth } \\
\text { od }\end{array}$ & $\begin{array}{l}\text { Mea } \\
\text { sure } \\
\text { men } \\
\text { t } \\
\text { Ran } \\
\text { ge }\end{array}$ & $\begin{array}{l}\text { Lowest } \\
\text { Detecti } \\
\text { on } \\
\text { Limit }\end{array}$ & $\begin{array}{l}\text { Sampli } \\
\text { ng } \\
\text { Durati } \\
\text { on }\end{array}$ \\
\hline $\begin{array}{l}\text { Carbon } \\
\text { monoxide } \\
\text { (CO) }\end{array}$ & $\begin{array}{l}\text { Non } \\
\text { Dispersive } \\
\text { Infrared } \\
\text { Absorption } \\
\text { (NDIR) }\end{array}$ & $\begin{array}{l}\text { HORIB } \\
\text { A } \\
\text { APNA } \\
360 \\
\text { CO } \\
\text { Analyz } \\
\text { er }\end{array}$ & $\begin{array}{l}40 \\
\text { CFR } \\
\text { Part } \\
50, \\
\text { App. } \\
\text { C } \\
\text { (US-E } \\
\text { PA) } \\
\end{array}$ & $\begin{array}{l}0- \\
100 \\
\text { ppm }\end{array}$ & $\begin{array}{l}0.02 \\
\text { ppm }\end{array}$ & 24 hour \\
\hline $\begin{array}{l}\text { Sulfur } \\
\text { Dioxide } \\
\text { (SO2) }\end{array}$ & $\begin{array}{l}\text { UV } \\
\text { fluorescenc } \\
\mathrm{e} \\
\text { (UVF) }\end{array}$ & $\begin{array}{l}\text { HORIB } \\
\text { A } \\
\text { APNA } \\
360 \\
\mathrm{SO} 2 \\
\text { Analyz } \\
\text { er }\end{array}$ & $\begin{array}{l}\text { EQSA } \\
- \\
0197- \\
114 \\
\text { (US-E } \\
\text { PA) }\end{array}$ & $\begin{array}{l}0-0 . \\
5 \\
\text { ppm }\end{array}$ & $0.5 \mathrm{ppb}$ & 24 hour \\
\hline $\begin{array}{l}\text { Nitrogen } \\
\text { Dioxide } \\
\text { (NOx) }\end{array}$ & $\begin{array}{l}\text { Reduced } \\
\text { Pressure } \\
\text { Chemilumi } \\
\text { nescence } \\
\text { (CLD) }\end{array}$ & $\begin{array}{l}\text { HORIB } \\
\text { A } \\
\text { APNA } \\
360 \\
\text { NOx } \\
\text { Analyz } \\
\text { er }\end{array}$ & $\begin{array}{l}40 \\
\text { CFR } \\
\text { Part } \\
50, \\
\text { App F } \\
\text { (US-E } \\
\text { PA) } \\
\end{array}$ & $\begin{array}{l}0-0 . \\
5 \\
\text { ppm }\end{array}$ & $0.5 \mathrm{ppb}$ & 24 hour \\
\hline
\end{tabular}

Heritage properties made of stone, Clad stone, marble, Brick etc may be affected by the environmental pollution as studied all over the world. The pollutant substances may not only dissolve the stone and deteriorate its value but can also cause destruction in the structures as well. [1]

\section{OBJECTIVES}

The main purpose of trhis research is to find out the impact of traffic pollution particularly on historic buildings in Lahore.The use of modern technologies like GIS is very helpful to determine the analysis especially in visual and spatial context.

\section{Methodology}

GIS is helpful in determining the pollution impact with in a distance of an activity by identifying the spatial feature. The use of GIS by identifying the pollution affect on historic buildings is not very old. The recent history tells us that interpolation method on dispersion modeling is being used for the GIS based analysis of pollutant. [12] Ambient air quality monitoring was conducted at advised sampling locations to assess the

Concentration of priority pollutants, (CO) Carbon monoxide, Oxides of Nitrogen (NO2), Sulfur dioxide (SO2), VOC, $\mathrm{CO} 2$, PM2.5 and PM10). Selection of sampling location is based on the Environmental factors including wind direction on the particular day and amount of turbulence in the air etc. The sampling was conducted for 24 hours. Reference method used for the measurements are included as Depending these sources, approximate locations of all points where deemed considerable in terms of air quality exposure in the main route within the limits of the study area have been determined by means of IKONOS satellite image.

A.Steps Involved in GIs Data Base Analysis

\begin{tabular}{|c|c|c|}
\hline Action Taken & Instruments/Methods & Timming \\
\hline $\begin{array}{l}\text { Registration of } \\
\text { Coordinates }\end{array}$ & $\begin{array}{l}\text { System of WGS } 84 \text { brand } \\
\text { Handy GPS }\end{array}$ & 24 hours \\
\hline $\begin{array}{l}\text { Settlement of } \\
\text { Points }\end{array}$ & Inspection of Land & \\
\hline $\begin{array}{l}\text { Pollution, Sound } \\
\text { and Vibration } \\
\text { Level Meter \& } \\
\text { analyzer }\end{array}$ & Pollutant level & $\begin{array}{l}\text { Morning,Noon and } \\
\text { Evening }\end{array}$ \\
\hline $\begin{array}{l}\text { ArcGIS } \\
\text { program }\end{array}$ & $\begin{array}{l}\text { ambient Air quality+ Noise } \\
\text { Map+ air quality map }\end{array}$ & -------------- \\
\hline
\end{tabular}

In addition to above, the coordinates of such points that were taken from handy GPS have been moved to ArcGIS software as point layer with the satellite image .To express the point data in spatial extent geostatistical interpolation methods are used and calculate the values of the fields between the points based on the feature data referenced to point geometry and express the results as raster surfaces.

Particularly, now adays for many commercial users of GIS the geostatistical interpolation methods are presented as useful tool to calculate the surface heights .Geostatistical analyst module is used for measuring pollution values in the 24 hours. In this module, three different geostatistical interpolation methods have been used which are as follows:

- Inverse Distance Weightage Method

- Ordinary Kriging (OK) Method

- Radial Basis Functions (RBF) Method

When there are unknown values and weighted point data then surface data is calculated by Inverse Distance Weight (IDW) .In this method, weight is described as the function of the distance between the points. In this extent, the wider distance, the weaker functions effects.

The other prevailing method is Kriging these techniques create surfaces that incorporate the statistical properties of the measured data (ESRI 2001). Categories of Kriging are linear and non-linear. Linear methods include Simple (SK), Ordinary (OK) and Universal (UK) Kriging; Non-linear methods include Indicator (IK), Probability (PK) and Disjunctive (DK) Kriging (URL-3; ArcGIS. 2008).

- RBF methods are a series of exact interpolation techniques; that is, the surface must pass through each measured sample value. RBFs are conceptually similar to fitting a rubber membrane through the measured sample values 
while minimizing the total curvature of the surface. The basis function to be selected determines how the rubber membrane will fit between the values (URL-3; ArcGIS. 2008).

- On basis of IDW, OK and RBF the GIS maps have been established for the purposes of researching suitable geostatistical interpolation method for noise mapping, these are based on equivalent continuous GHG level of twenty four hours monitoring. Pollution maps modeled by the IDW method have been shown in DEM generated by ARC GIS.

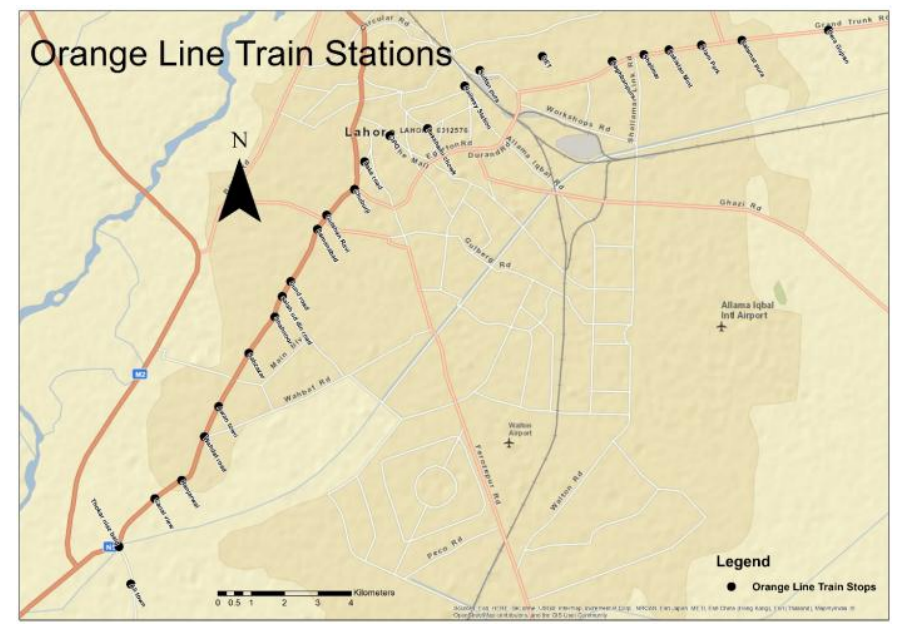

Fig. 1

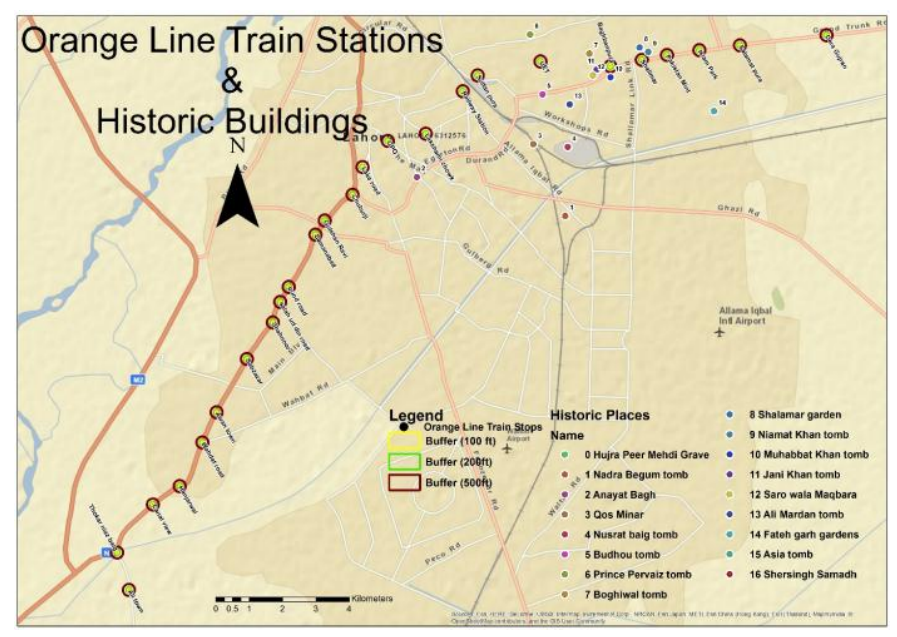

Fig. 2

\section{B.Interpolation Maps/Stress Maps}

By using Kriging stress maps have been generated from air pollutant data for the area of Lahore

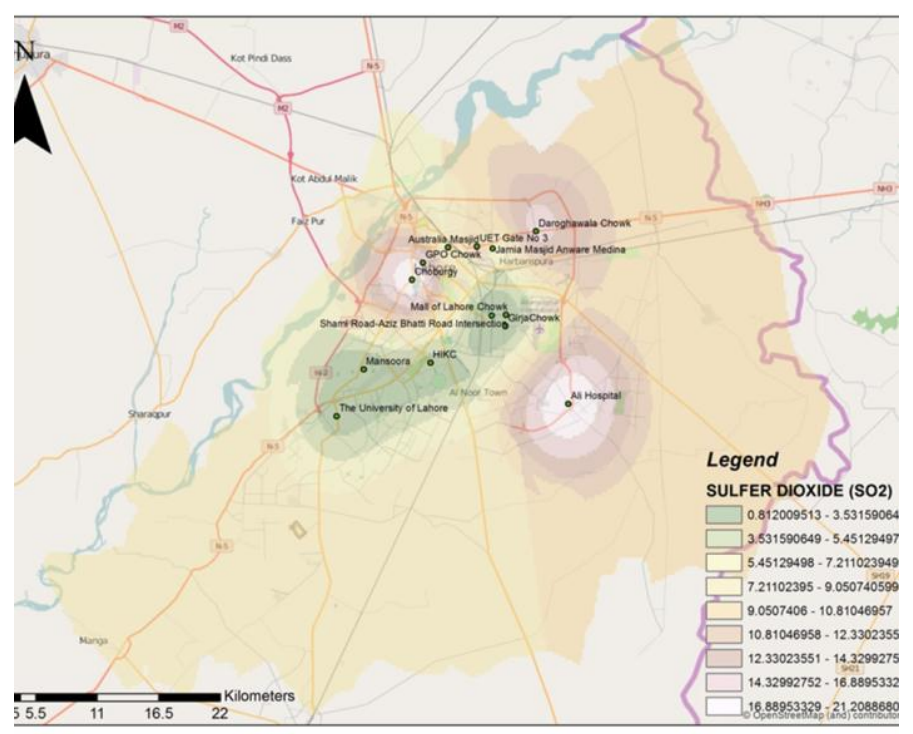

Fig. 3

\section{CONCLUSION}

The stress maps generated in ARC GIS (Arc map) shows that the effect of pollution gases $\mathrm{SO}_{2}$ and $\mathrm{NO}_{2}$ and particulate matters on historic buildings above mentioned is beyond the negative impacts except Choburgy and Austalia mosque as the NEQs values are not high in these areas because of the distance from the main road. Choburgy is located at the busiest junction where the concentration of these gases is high and above NEQs standard limits.

\section{RECOMMENDATIONS}

- There should be proper emission standards for the vehicles which are to be followed

- The government should respond to the crises and give an effective straight roadmap to reduce the toxic risk from vehicular increase.

- An effective committee must formed which respond to mounting evidence on deteriorating air quality and heritage damages associated with the modern developments and vehicular fumes.

- Sound barriers between 5and $15 \mathrm{db}$ of noise reduction should be installed depending upon the height and relevant location along the track.

- In order to radically increase the clean air facilitate the green cover

- Restrict lifecycle of impound pollutant vehicles.

- Urban and regional development should be linked with the historic district.

- Extensive public awareness and local community involvement at the heart of revitalization projects.

- Inhabitants should be facilitated with improved living and working conditions.

- There should be a focus on enhancing public spaces and improving cultural and natural resources.

- Social networks maintenance and cultural diversity should be encouraged. 
- Tourism sustainability management with various spheres of activities Capitalize on political will and mutual interest should be ensure.

- Historic district from the rest of the city should be distinguished.

\section{REFERENCES}

[1] Yoichi, Nishiyama. 1993. "Effect of air pollution on Cultural Properties." Bullitin of Research Institute NARA Institute Japan 1 (1): 101-114. Accessed 2016.

[2] Yoichi, NISHIYAMA. 19995. "Measurement of Atmospheric Pollution in the Vicinity of Cultural Properties and its Effect." Preservation and restoration of Historical Records, Japan.

[3] S.Gamati. 2015. "Monitoring the Quality of Air." Encyclopedia of Life Support System II.

[4] C.L., Miles S.B. and Ho. 1998. "Application and Issues of GIS as Tool for Civil Engineering Modeling." Journal of computing in civil engineering 13 (3): 144-152. Accessed 2016.

[5] J., Thapa K. and Bossler. 1992. "Accuracy of spatial Data used in GIS." Photogrammatic Engineering and Remote Sensing 58,841-858. Accessed 2016.

[6] EIONET. 2010. Air Base. June. Accessed 2016. http://air-climate.eionet.europa.eu/databases/airbase/

[7] Mahmmod. A Khawaja, Shaheen Rafi Khan. 2000. Air pollution. Vol. 1. Islamabad. Accessed 2016.

[8] Charron, A. and R.M HArrison. 2003. "Primary particle formation from vehicle emission during exhaust dilution in the roadside atmosphere." 4109-4119. Accessed 2016.

[9] Vousta, D., C. Samara, T. Kouimtzis, K. Ochsenkuhn. 2002. "Elemental composition of air born particulate matter in themulti-impacted urban area of thessaloniki,." 36:4453-4462.

[10] John Watt, Johan Tidblad,Crabbe, Ron hemilton and Halen. 2006. The Effect of Air Pollution on Cultural Heritage. Edited by John Tidblad,Vladimir Kucera, Ron Hamilton John Watt. Newyork: SPRINGER. doi:10.1007/978-0-387-848893-8.

[11] S. GULZAR, M.N.CHAUDHRY AND JEAN PIERRE BERG. 2013. "Chemical and Mineralogical Characterization of Old." ASIAN JOURNAL OF CHEMISTRY 25: 133-138.

[12] Kunzli, N., Kaiser, R., Medina, S.,--. 2000. "Public health impact of outdoor and traffic related air pollution." A European Context (Lancet) (356): 795-801

[13] Khardori, A. Studies, E. 2000. "Health based standards in the clean air Act." BA paper, Environment Science. University of Chicago, US.

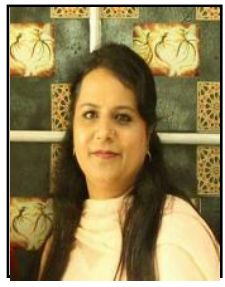

\section{Rummana Khan Sherwani}

Place: Lahore Pakistan

Date of Birth: $28^{\text {th }}$ December, 1977

completed high school from Divisional Public school

Lahore

Bachelors in City \& Regional Plkanning from

University of Engineering and Technology Lahore.

(2001)

Master in Geographical information System from University of the Punjab (2007)

M. Arch from University of the Punjab

Master s Student University of Engineering and Technology Lahore.

Worked as a Senior Urban Planner and GIS Analyst in Asian Consulting

Engineers Lahore Pakistan.

Worked in Lahore College for Women University Lahore.

(August 2014 till June 201) as a visiting faculty member.

Worked in NUSSK ASSOCIATES as a Senior consultant from 2001 to Date.
Currently working as an Assistant Professor in University of Management \& Technology, Lahore, Pakistan.

She has been engaged in master planning of several housing schemes, Industrial estates, Master planning of Educational Institutes and universities of national prestige and importance. A hand on experience on implementation of GIS technology in urban planning and historic building conservation.

Over 15 years of experience of research, administration and designing of Housing schemes, Industrial Estates, Master planning , architectural \& Planning projects concerning issues of architectural conservation, housing, Urban design, Urban regeneration and commercial buildings etc.

Dr. Zareen Shahid is an Assistant professor of school of Architecture \& City and Regional Planning in University of Engineering \& Technology Lahore.

Dr. Muhammad Asim is an Assistant professor of school of Architecture \& Planning in University of Engineering \& Technology Lahore. 